\title{
Mediterranean Heathland as a Key Habitat for Fire Adaptations: Evidence from an Experimental Approach
}

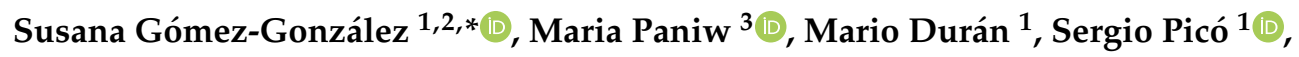 \\ Irene Martín-Rodríguez ${ }^{4}\left(\mathbb{C}\right.$ and Fernando Ojeda ${ }^{1}$ (1) \\ 1 Departamento de Biología-IVAGRO, Universidad de Cádiz, Avenida República Árabe Saharawi, s/n, \\ 11510 Puerto Real, Spain; marioduran1968@gmail.com (M.D.); sergio.pico@uca.es (S.P.); \\ fernando.ojeda@uca.es (F.O.) \\ 2 Center for Climate and Resilience Research (CR)2, Avenida Almirante Blanco Encalada, 2002, \\ Santiago 8370449, Chile \\ 3 Ecological and Forestry Applications Research Centre (CREAF), Campus de Bellaterra (UAB) Edifici C, \\ 08193 Cerdanyola del Vallès, Spain; maria.paniw@creaf.uab.cat \\ 4 Área de Biodiversidad y Conservación, Departamento de Biología, Geología, Física y Química Inorgánica, \\ ESCET, Universidad Rey Juan Carlos, Calle Tulipán s/n, E-28933 Móstoles, Spain; irene.martin@urjc.es \\ * Correspondence: susana.gomez@uca.es; Tel.: +34-956-016-090
}

Received: 2 June 2020; Accepted: 7 July 2020; Published: 10 July 2020

check for updates

\begin{abstract}
Some fire ecology studies that have focused on garrigue-like vegetation suggest a weak selective pressure of fire in the Mediterranean Basin compared to other Mediterranean-type regions. However, fire-prone Mediterranean heathland from the western end of the Mediterranean Basin has been frequently ignored in the fire ecology literature despite its high proportion of pyrogenic species. Here, we explore the evolutionary ecology of seed traits in the generalist rockrose Cistus salviifolius L. (Cistaceae) aiming to ascertain the role of the Mediterranean heathland for fire adaptations in the Mediterranean Region. We performed a germination experiment to compare the relationship of seed size to (i) heat-stimulated germination, (ii) dormancy strength, and (iii) heat survival in plants from 'high-fire' heathland vs. 'low-fire' coastal shrubland. Germination after heat-shock treatment was higher in large seeds of both 'high-fire' and 'low-fire' habitats. However, dormancy was weaker in small seeds from 'low-fire' habitats. Finally, seed survival to heat shock was positively related to seed size. Our results support that seed size is an adaptive trait to fire in C. salviifolius, since larger seeds had stronger dormancy, higher heat-stimulated germination and were more resistant to heat shock. This seed size-fire relationship was tighter in 'high-fire' Mediterranean heathland than 'low-fire' coastal shrubland, indicating the existence of differential fire pressures and evolutionary trends at the landscape scale. These findings highlight the Mediterranean heathland as a relevant habitat for fire-driven evolution, thus contributing to better understand the role of fire in plant evolution within the Mediterranean region.
\end{abstract}

Keywords: Cistus; germination; dormancy; fire-driven evolution; Mediterranean-type ecosystems

\section{Introduction}

The importance of fire in the evolutionary history and diversity of plants from Mediterranean-type ecosystems is widely acknowledged [1,2]. The apparent convergence of functional traits among plant species from these distant ecosystems is explained by comparable fire regimes [3], in addition to similar climatic conditions (e.g., traits related to summer drought tolerance such as leaf sclerophylly; [4]). 
Some examples of fire-related convergent traits are post-fire resprouting from lignotubers [5], fireproof thick bark [6], aerial seed-bank (i.e., serotiny; [7]), and fire-triggered germination of dormant seeds [8].

In species whose adults are killed by fire but seeds are stimulated to germinate (i.e., seeder species), seed traits are particularly important in mediating fire responses [9]. Seeder species produce dormant seeds that form a long-lived seed bank whose germination is stimulated by fire cues such as heat shock or chemicals from smoke and ashes $[8,10]$. It is well established that the fire regime (particularly fire intensity) shapes the heat-shock temperature threshold needed for dormancy release in species with fire-stimulated germination [11]. At the same time, seed responses to fire are ultimately mediated by seed traits, such as seed coat thickness and pubescence [12,13], seed moisture [14], and seed size or weight [15-18]. This later trait is the more frequently investigated seed trait in the fire ecology literature, but studies have shown contrasting patterns depending on the species, ecosystems, or fire regimes. For example, seed size (or weight) and post-fire germination were negatively correlated in Australian species [15,17] but positively correlated in some Mediterranean species (e.g., Cistus spp.; [16,18]), whereas no correlation was found for European grassland species [19]. Since seedlings from small seeds cannot emerge from deep soil depths, small seeds in fire-prone habitats need to be more resistant to fire since they are exposed to intense fire at shallow depths [17]. In some species (e.g., Cistus spp.), however, larger seeds might be selected by fire since they have competitive advantages in the post-fire environment related to early emergence and higher seedling vigor [18]. All in all, the evolutionary ecology of seed traits associated with post-fire germination is still poorly understood [17,20]. Since fire adaptations are species-specific (e.g., [21]), exploring how seed traits such as dormancy strength or size vary with the fire regime requires the analysis of the relationship between seed trait variability and post-fire responses at the intraspecific level $[20,22,23]$.

Although all Mediterranean-type ecosystems are subject to frequent summer fires, fire regimes can vary even at the landscape scale, as some habitats or plant communities are more fire-prone than others. This variability is in part determined by soil fertility: plant communities on nutrient-poor, acid soils seem to be more flammable and, hence, more fire-prone than those on richer soils, thus generating differences in the frequency of adaptive traits to fire at the regional scale (e.g., [24]). For example, fire adaptations in the Mediterranean western Cape Floristic Region (South Africa), are far more frequent in fynbos (nutrient-poor, acid soils) than in thicket (richer soils) or coastal shrublands (strandveld), although these habitats co-occur in the landscape [25,26]. Similarly, in the western Mediterranean Basin, the proportion of species with fire-stimulated germination was higher in Mediterranean heathland (acid, nutrient-poor soils) than in garrigue-like shrublands (more fertile soils; [24]). Since the investigation of the role of fire in the evolution of Mediterranean species in the Mediterranean region has traditionally focused on garrigue vegetation (e.g., [27-30]), comparative studies have shown that fire-recruiting species are less frequent in the Mediterranean Basin than in other Mediterranean-type regions, thus concluding that fire-selective pressures would not have been so strong in the Mediterranean region [1,31]. However, the highly fire-dependent Mediterranean heathland habitat [24], although less abundant than the garrigue, has a non-negligible, wide range in the western Mediterranean Basin [32]. Therefore, studying the role of fire as a selective pressure in this habitat could bring new insights into the importance of fire in plant evolution in the Mediterranean region.

Here, we explored the evolutionary ecology of seed traits in relation to fire in Mediterranean heathland plants in order to ascertain the importance of this fire-prone habitat for fire adaptations. To do so, we used the Mediterranean seeder species Cistus salviifolius L. (Cistaceae) as a case study. This is a generalist species that occurs in fire-prone Mediterranean heathland patches [33], but is also frequent in not, or much less, fire-prone habitats, such as coastal shrublands [34] with similar climatic conditions, thus providing an opportunity to address key fire-selection hypotheses. Cistus salviifolius seeds have a physical dormancy that is broken by heat shock [11,16,35]. Variability in seed dormancy and heat-shock stimulation has been reported both within [16] and among populations [22]. That variability has been related to seed size at the within-population level, showing that large seeds have a higher probability 
of germination after heat-shock treatment than small seeds [16]. However, those patterns have not been associated with different fire regimes.

We carried out a germination experiment in which seeds of plants from populations of 'high-fire' heathland and 'low-fire' coastal habitats had their size (estimated as surface area) recorded and were either exposed or not exposed to a heat-shock treatment. We predicted that, if fire has a more preponderant role in shaping seed traits in 'high-fire' heathland than in 'low-fire' coastal shrubland, populations from heathland sites will show stronger correlations between seed size and (i) heat-stimulated germination, (ii) dormancy strength, and (iii) survival to heat-shock, than those from coastal shrubland sites.

\section{Materials and Methods}

\subsection{Study Species}

Cistus salviifolius L. (Cistaceae) is a common rockrose species in the Iberian Peninsula with a broad geographic distribution across the Mediterranean Basin [22]. It can be found in a wide variety of ecosystems on different soil-types and under different fire regimes. It has fire-stimulated seed germination [35], but recruitment has also been reported in unburned areas [36]. Since adult plants do not resprout and are thus killed by fire, this species can be referred to as seeder [37]. It is a small shrub, $20-90 \mathrm{~cm}$ high, with radiate white flowers and dry capsules containing globose, reticulate seeds [38]. Flowering occurs in early spring and fruiting in summer [39].

\subsection{Study Area, Populations and Seed Collection}

Seeds were collected in 15 natural populations from the Strait of Gibraltar region, at the southernmost tip of Spain (Figure 1). Climate in this area is mild Mediterranean, with cool rainy winters and warm dry summers. Mean annual temperature is $17.6^{\circ} \mathrm{C}$ and mean annual rainfall is $908.6 \mathrm{~mm}$ [40]. Nine of the 15 populations were located in fire-prone Mediterranean heathland patches ('high-fire'), which harbour a large proportion of pyrogenic species (e.g., Cistus populifolius, Calluna vulgaris, Erica australis, Genista tridens) and is considered a fire-adapted vegetation (FigureS1; [24]). The remaining six populations were located in coastal shrublands ('low-fire'), where fire pressure seems to have been lower at an evolutionary time scale, as vegetation is dominated by non-pyrogenic species (e.g., Pistacia lentiscus, Halimium calycinum, Juniperus spp.; [34]) (Figure S1). Although current fire frequencies are similar in both habitats (Table S1) due to anthropogenic activities [41], fire-related traits of dominant species of these two habitats indicate that fire has historically been a much more relevant selective agent in Mediterranean heathland than in coastal shrubland, as it occurs in the South African fynbos-coastal shrubland system [26]. In each population, we collected seeds from mature capsules of 15 randomly selected individuals, at least $5 \mathrm{~m}$ apart from each other. Seeds from each individual were placed in labelled paper bags and preserved in the lab at room temperature and dark conditions for approximately six months until the germination experiment commenced. 


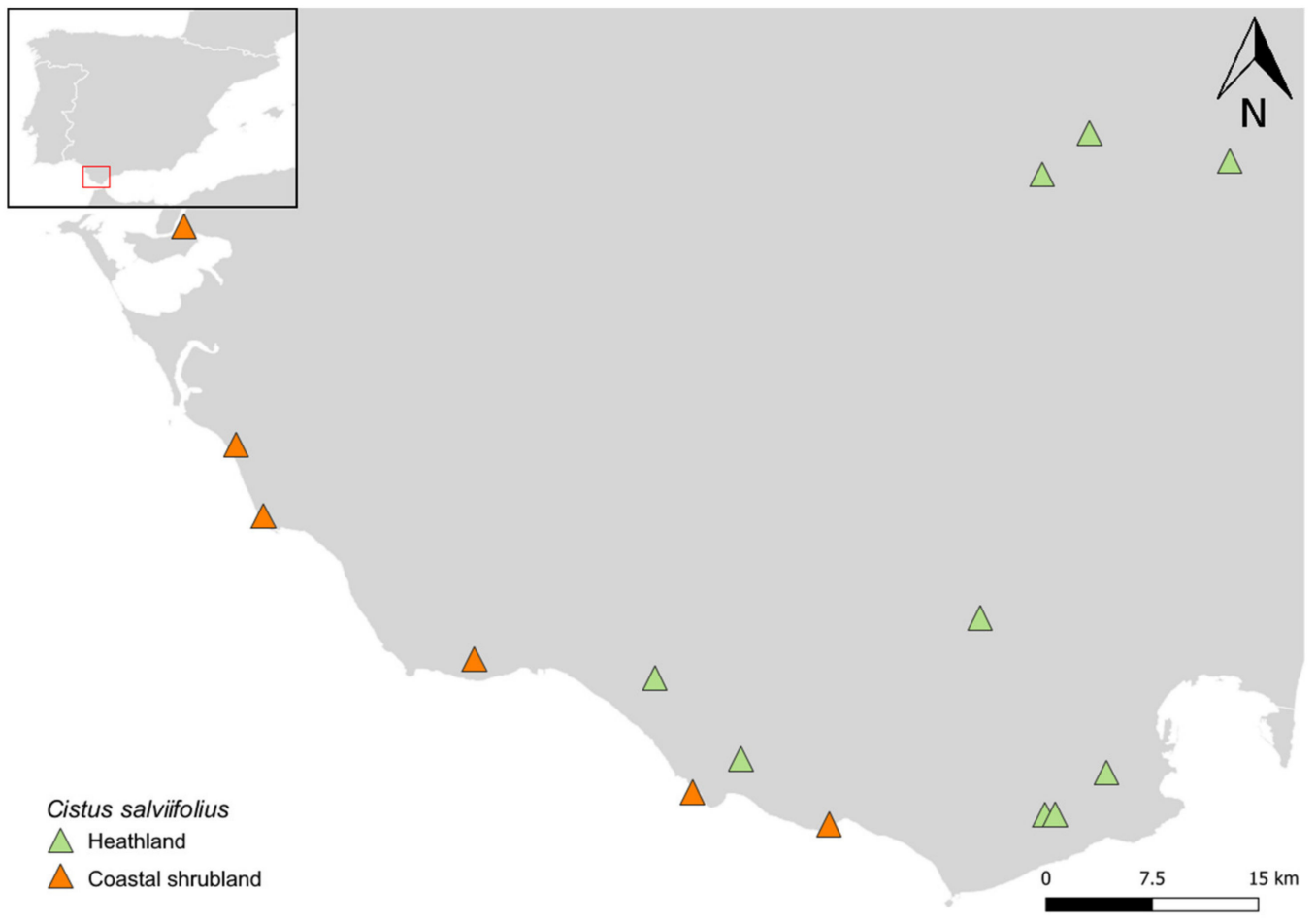

Figure 1. Site location of the sampled Cistus salviifolius populations from Mediterranean heathland ('high-fire') and coastal shrubland ('low-fire') sites in the Strait of Gibraltar area, at the southernmost tip of Spain. See Table S1 for additional information on sampling sites.

\subsection{Seed Size Measurement and Germination Experiment}

Seed surface area was used as a proxy for size (as in previous studies; e.g., [13]) and was measured under a Digital Microscope Leica(C) DMS1000 with LAS (Leica Application Suite) V4.4.0 software. We measured the surface area (hereafter called seed size for simplicity) of six randomly selected seeds per individual and then obtained the average value of each individual plant to be used in the analyses.

We then conducted a growth-chamber germination experiment to assess (i) the proportion of dormant seeds, (ii) the effect of heat-shock on the probability of seed germination, and (iii) the survival of seeds to heat-shock, at the individual (plant) level, and then relate these variables to (average) seed size of each plant. From each of the 15 plants per population, we allocated 12 seeds to a heat-shock treatment, and 12 were not treated (control). The number of seeds per individual and treatment was lower than 12 in some instances due to limitations in seed availability (many seeds were predated; File S1). For the heat-shock treatment, seeds of each plant were placed on small aluminum trays in a dry oven (Dry-Big JP Selecta ${ }^{\circledR}$ S.A., Barcelona) and were exposed to $120^{\circ} \mathrm{C}$ during $5 \mathrm{~min}$, following previous germination experiments performed in this species [11,16].

After the heat shock, seeds of each plant and treatment (heat-shock and control) were placed in labelled Petri dishes with filter paper, introduced in a growth chamber (Fitoclima S600; Aralab, Lisbon) at $20^{\circ} \mathrm{C}$ constant temperature and dark conditions (C. salviifolius seed germination is not affected by light conditions; [35]) and watered periodically with distilled water. These conditions were applied to maximize germination based on a previous study [22]. Every two days, seeds were checked for germination, and were considered as germinated when the radicle was visible more than $1 \mathrm{~mm}$. Germinated seeds were removed from the Petri dishes once they were counted. This germination assay lasted 90 days, after which viability of non-germinated seeds (from both control and treated samples) was tested with tetrazolium staining (TTC 1\% in phosphate buffer, $\mathrm{pH} 7.3$, and $24 \mathrm{~h}$ in dark). The tetrazolium was applied to seeds cut in half to expose the embryo and facilitate the staining. By doing so, the number of germinated seeds and the number of total viable seeds (germinated plus tetrazolium-positive seeds) for each individual and treatment were 
calculated. Dormancy strength was then estimated as the proportion of non-germinated, viable seeds (i.e., dormant seeds) in control samples. Heat-shock survival was calculated as the number of seeds alive (germinated plus non-germinated, viable seeds) in heat-treated samples.

\subsection{Statistical Analyses}

To assess whether the relationship between seed size and heat-stimulated germination depended on the type of habitat, we performed three-factor generalized linear mixed models (GLMM). In these models, the proportion of germinated seeds was the dependent variable (binomial distribution) and the independent variables were seed size (continuous), heat shock treatment (heat vs. control), and habitat type ('high fire' vs. 'low-fire'). The difference between habitats in the seed size-dormancy relationship was evaluated using a two-factor GLMM, in which the dependent variable was the proportion of dormant seeds in control samples (binomial distribution) and the independent variables were seed size and habitat type. Finally, to assess the differences in the relationship between seed size and heat-shock survival in function of habitat type, we used a two-factor GLMM where the dependent variable was the proportion of total viable seeds after heat-shock (binomial distribution) and the independent variables were seed size and habitat type ('high fire' vs. 'low-fire'). In all these models, population was included as random factor to account for the dependence of the data. The effect of fixed factors was evaluated by forward model selection and likelihood ratio test (LRT) [42]. We calculated the Nakagawa's $R^{2}$ for mixed models; the marginal $R^{2}$ for fixed effects and the conditional $R^{2}$ for both fixed and random effects [43]. All analyses were performed with R software [44] using the lme4 package [45].

\section{Results}

The average seed viability was $85.6 \pm 1.2 \%$ (mean \pm SE) in control and $80.4 \pm 1.5 \%$ in heat-shock treated plants. Average seed germination was $8.5 \pm 0.9 \%$ and $78.2 \pm 5.2 \%$ in control and heat-shock samples, respectively. Seed germination was stimulated by heat shock in plants from both 'high-fire' heathland habitats and 'low-fire' coastal shrublands, although this stimulation tended to be higher in 'high-fire' habitats (marginally significant heat $\times$ habitat interaction; Table 1, Figure 2, Table S2) and varied among populations (significant random effect on heat slope; $\chi^{2}=73.12, p<0.001$ ). Besides, heat-shock effect on seed germination depended on seed size (highly significant heat $\times$ size interaction; Table 1 ), as germination after heat-shock was higher for larger seeds in both 'high-fire' and 'low-fire' habitat types. By contrast, germination of small seeds in control samples was considerably higher in plants from 'low-fire' habitats than in those from 'high-fire' (Figure 2), as also indicated by a significant heat $\times$ size $\times$ habitat interaction (Table 1 ).

Table 1. Results of likelihood ratio tests (LRTs) showing the effects of heat shock, seed size, habitat type and their interactions on seed germination of Cistus salviifolius. All models included population as random factor. Significant $p$-values $(<0.05)$ are highlighted in bold.

\begin{tabular}{ccccc}
\hline Model & No. of Parameters & Deviance & $\chi^{\mathbf{2}}$ & $p$ \\
\hline Intercept & 4 & 2086.7 & & \\
\hline Heat & 5 & 2041.8 & 44.91 & $<\mathbf{0 . 0 0 1}$ \\
\hline Heat + Size & 6 & 2041.6 & 0.21 & 0.645 \\
\hline Heat + Habitat & 6 & 2040.5 & 1.29 & 0.255 \\
\hline Heat $\times$ Size & 7 & 2013.2 & 28.63 & $<\mathbf{0 . 0 0 1}$ \\
\hline Heat $\times$ Habitat & 7 & 2036.7 & 5.16 & 0.075 \\
\hline Heat $\times$ Size $\times$ Habitat & 11 & 2000.2 & 12.97 & $\mathbf{0 . 0 1 1}$ \\
\hline
\end{tabular}




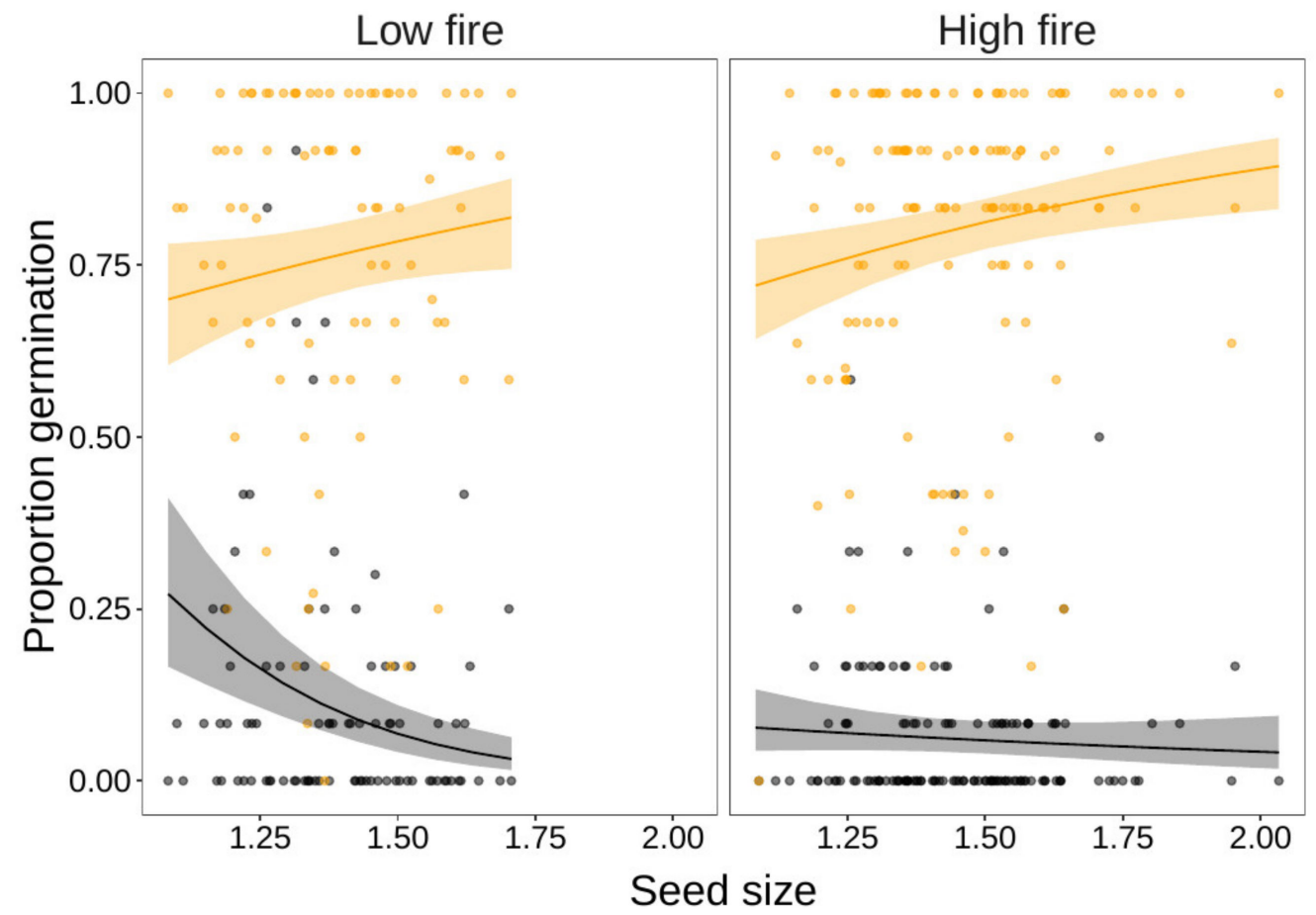

Figure 2. Relationship between germination (proportion germinated) and seed size $\left(\mathrm{mm}^{2}\right)$ in Cistus salviifolius, in 'low-fire' coastal shrubland and 'high-fire' Mediterranean heathland habitats. Dots represent plant individuals (grey: control; orange: heat-shock treated). Regression lines and 95\% confidence intervals of predicted models are shown (seed size ranged from 1.08 to 2.03). Conditional $R^{2}=0.55$ and marginal $R^{2}=0.52$.

This corresponds to results of dormancy strength, lower in small-sized control seeds of plants from 'low-fire' habitats than in those from 'high-fire', rendering a significant size $\times$ habitat interaction (Table 2, Figure 3). Finally, seed survival to heat-shock treatment was higher in larger seeds (significant size effect; Table 2, Figure 4). Although in this variable the size $\times$ habitat interaction was not significant (Table 2), plants from 'high-fire' habitats tended to have a more positive relationship between seed size and heat survival compared to 'low-fire' habitats (Figure 4 and see also Table S3).

Table 2. Results of likelihood ratio tests (LRTs) showing the effects of seed size, habitat type and their interactions on dormancy strength and heat survival of Cistus salviifolius. All models included population as random factor. Significant $p$-values $(<0.05)$ are highlighted in bold.

\begin{tabular}{ccccccccc}
\hline & \multicolumn{3}{c}{ Dormancy Strength } & \multicolumn{4}{c}{ Heat Survival } \\
\cline { 2 - 9 } & $\begin{array}{c}\text { No. of } \\
\text { Parameters }\end{array}$ & Deviance & $\chi^{2}$ & $p$ & $\begin{array}{c}\text { No. of } \\
\text { Parameters }\end{array}$ & Deviance & $\boldsymbol{\chi}^{\mathbf{2}}$ & $\boldsymbol{p}$ \\
\hline Intercept & 2 & 1182.8 & & & 2 & 1215.5 & \\
\hline Habitat & 3 & 1164.1 & 1.69 & 0.194 & 3 & 1212.7 & 2.71 & 0.100 \\
\hline Size & 3 & 1181.1 & 17.0 & $\mathbf{< 0 . 0 0 1}$ & 3 & 1203.8 & 11.68 & $<\mathbf{0 . 0 0 1}$ \\
\hline Size $\times$ Habitat & 5 & 1156.1 & 8.07 & $\mathbf{0 . 0 0 5}$ & 5 & 1199.0 & 4.80 & 0.090 \\
\hline
\end{tabular}




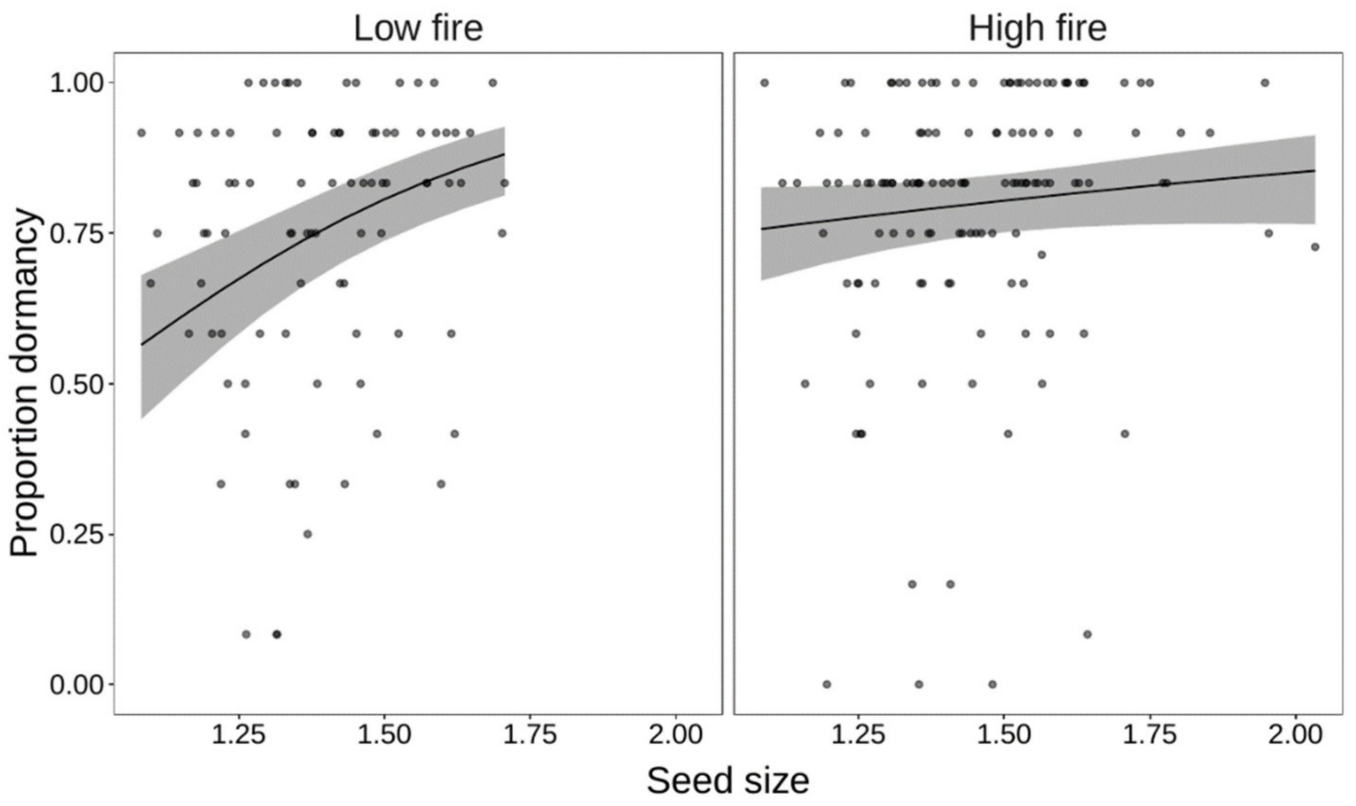

Figure 3. Relationship between dormancy and seed size $\left(\mathrm{mm}^{2}\right)$ in Cistus salviifolius, in 'low-fire' coastal shrubland and 'high-fire' Mediterranean heathland habitats. Dots represent plant individuals. Regression lines and 95\% confidence intervals of predicted models are shown (seed size ranged from 1.08-2.03). Conditional $R^{2}=0.08$ and marginal $R^{2}=0.03$.

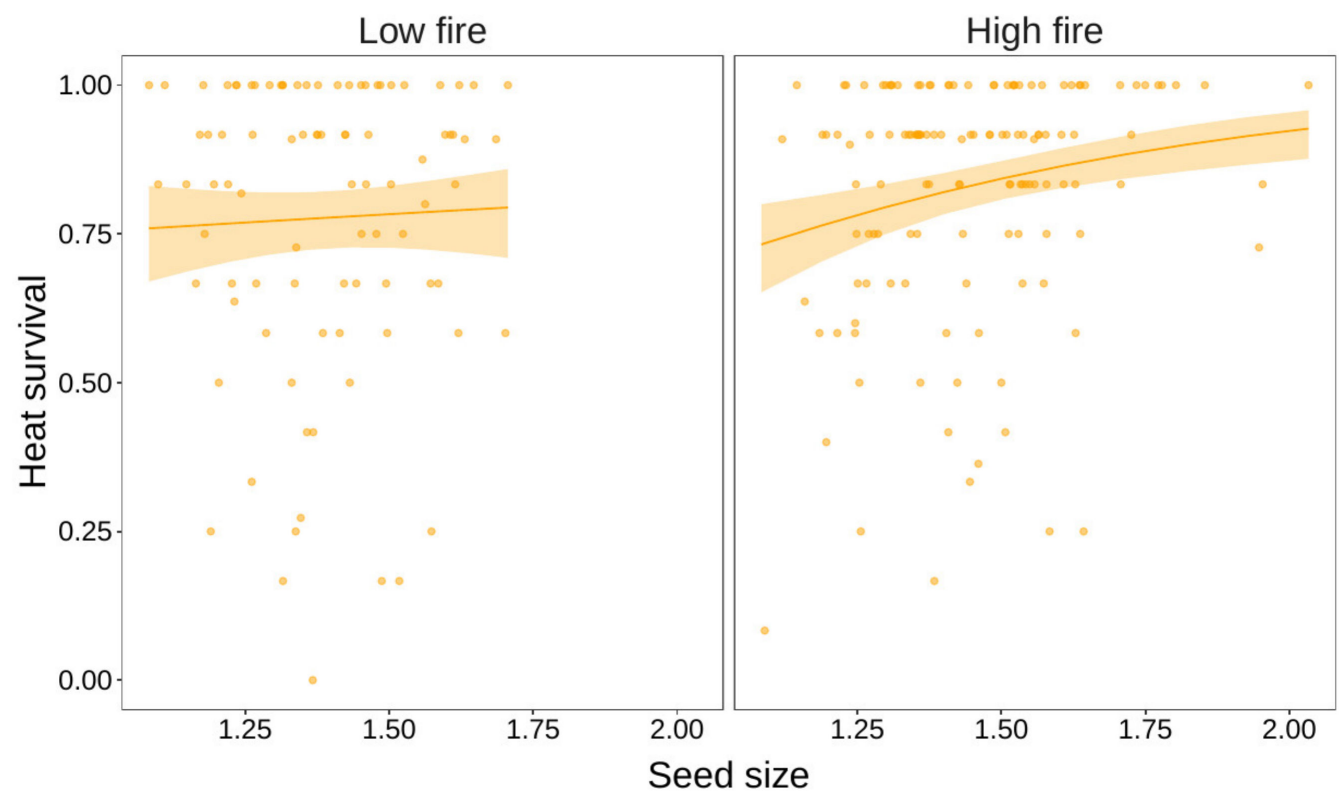

Figure 4. Relationship between seed survival to heat shock and seed size $\left(\mathrm{mm}^{2}\right)$ in Cistus salviifolius, in 'low-fire' coastal shrubland and 'high-fire' Mediterranean heathland habitats. Dots represent plant individuals. Regression lines and 95\% confidence intervals of predicted models are shown (seed size ranged from 1.08 to 2.03). Conditional $R^{2}=0.05$ and marginal $R^{2}=0.02$.

\section{Discussion}

Our results showed that, in C. salviifolius seeds, the variation in the responses to heat shock (germination and survival) and dormancy strength relate to seed size. All these seed-trait-fire relationships were different between 'high-fire' Mediterranean heathland and 'low fire' coastal shrubland habitats, which indicates the existence of differential selective processes driven by fire at the landscape scale. 
The ability of C. salviifolius to successfully colonize post-fire environments is well established [46], as well as its physical seed dormancy and heat-shock stimulated germination $[11,16]$. Tavşanoğlu and Çatav (2012) [16] also found that seed size (estimated as seed mass in that case) in this species was positively correlated with germination after heat-shock treatment within a single population, but such correlation was not found in non-treated, control seeds, most of which remained dormant regardless of size. Our results corroborate their finding across populations, but only in 'high-fire' Mediterranean heathland habitats. In 'low fire' coastal shrubland habitats, by contrast, we found weaker seed dormancy and, consequently, higher germination than in 'high-fire' habitats for small seeds of control samples. This might imply that larger seed size is more advantageous, and thus adaptive, to resist heat-shock and germinate after fire. On the other hand, in 'low fire' coastal shrubland habitats, some seed germination and seedling recruitment would occur in the absence of fire because of the germination of weakly-dormant, smaller seeds. This can be seen as a bet-hedging strategy, allowing C. salviifolius populations to persist in habitats where wildfires are rare events with long fire-free periods, such as coastal shrublands [16]. Furthermore, the high variability we found in the heat-shock responses among populations and individuals suggests that other selective pressures are probably interacting with fire to shape seed traits in C. salviifolius and might in part explain the generalist character of this species.

Interestingly, the range of seed sizes was wider in 'high-fire' than in 'low-fire' habitats, where seeds with surface area greater than $1.75 \mathrm{~mm}^{2}$ were not found (Figure 2). This pattern, together with the facts that larger seeds tended to have (i) a higher probability of surviving heat shock, and (ii) higher heat-shock germination percentages in 'high-fire' sites, might indicate that fire is causing a directional selection on seed size in C. salviifolius populations from Mediterranean heathlands but not in those from coastal shrublands. In addition to that, the stronger dormancy of smaller seeds in 'high-fire' habitats supports the idea that, in the context of the Mediterranean region, fire has played a more relevant, evolutionary role in the Mediterranean heathland than in other Mediterranean shrublands [24]. This means that a strict fire suppression policy could have detrimental effects, not only on the viability of C. salviifolius populations from this habitat, but also on the population viability of many other Mediterranean heathland species. The Mediterranean heathland is a highly diverse, fire-prone ecosystem that harbours a great variety of singular, endemic species (e.g., Drosophyllum lusitanicum), including some postfire ephemerals such as Silene gaditana [47]. In the Mediterranean heathland, fire has driven plant diversity [48] and modulates the population dynamics of its distinctive plant species (e.g., [49]).

Although the proportion of variance explained by estimated models in the cases of heat-shock survival and dormancy strength was very low, we consider that the observed trend in these variables is biologically significant enough to suggest that seed size in C. salviifolius is an adaptive trait selected by fire. There are several functional reasons that could explain why larger seeds are adaptive to fire while smaller seeds are favoured in the absence of fire. First, larger seeds, producing larger seedlings, would be favoured under frequent fire in ecosystems where post-fire germination is profuse and within-species competition for recruitment is strong, as Delgado et al. (2008) [50] suggested for Cistus ladanifer. Second, larger seeds would protect the embryo more efficiently from elevated temperatures, thus allowing them to survive the heat pulse associated with the passage of fire ([51] and references therein). The latter explanation might be associated with the existence of a positive correlation between seed size and other traits that modulate seed dormancy and/or heat survival, such as testa thickness or hardseededness. Hardseededness certainly imposes physical dormancy, which is broken by fire (mainly due to the physical scarification generated by heat shock) in many pyrogenic species from fire-prone ecosystems [8], being a characteristic trait of the family Cistaceae [52-54]. Variation in hardseededness could explain the differences between habitats in heat shock survival, since it modulates seed moisture and the lethal temperature thresholds of seeds [14]. The correlated selection of seed traits explains the germination response to heat-shock in other species [20]. Nevertheless, fire-selection experiments are needed to test this hypothesis. On the other hand, as mentioned above, the interaction 
of fire with other selective pressures (e.g., seed predation, competition, nutrient availability) in shaping seed size in Cistus species cannot be discarded [16].

Contrasting results have been reported in other fire-prone environments (e.g., from Australia), where species with smaller seeds are more resistant to high temperatures than species with larger seeds $[14,15,17]$. As seedlings from small seeds are unable to emerge from deeper in the soil, they endure higher temperature thresholds, which allows them to survive the passage of fire in the soil surface, where seedling emergence is possible [17]. This variation in the association of seed size with germination after heat-shock among species or ecosystems could be a consequence of the complex interaction among seed size (and shape), seedling emergence and soil depth, which might generate species-specific responses to fire pressure [15,55]. Cochrane et al. (2015) [21] pointed out that environmental gradients do not necessary explain trait variation among populations and selective responses can be individualistic. Therefore, seed size alone should not be used as a predictor of post-fire recruitment success across species and ecosystems [15] and a wide variety of seeds traits need to be studied to better understand the evolutionary ecology of seeds [56]. Nonetheless, it is important to highlight that, despite the variability in the direction of fire-driven selection among species, our results provide evidence to support that fire is an evolutionary agent shaping seed traits in plant species from fire-prone ecosystems $[13,20]$. Understanding the role of fire in plant trait evolution and the ecological effects of trait variation with changes in fire regimes contribute to the knowledge of how plant communities are structured and, therefore, help develop adequate management policies for conservation at a regional scale [57].

\section{Conclusions}

Seed size in C. salviifolius is an adaptive trait to fire, since heat-shock responses (seed germination and survival), as well as dormancy strength were higher in large seeds. In C. salviifolius populations from 'high-fire' Mediterranean heathland sites, dormancy of small-sized seeds was stronger than in those from 'low-fire' coastal shrublands, suggesting the existence of differential fire selective pressures at the landscape scale. We cannot ascertain whether fire trait selection has occurred from 'low-fire' to 'high-fire' habitats or vice versa (i.e., acquirement of seed dormancy in 'high-fire' habitats or relaxation of dormancy in 'low-fire' habitats). In any case, our results illustrate that the fire-prone Mediterranean heathland is a key habitat for fire adaptations within the context of the Mediterranean region. Considering that the Mediterranean heathland is a singular habitat with great plant biodiversity and conservation values at a wide regional scale [32], management plans aimed to preserve this habitat should not ignore the role of fire as a key driver of its biodiversity.

Supplementary Materials: The following are available online at http://www.mdpi.com/1999-4907/11/7/748/s1, Figure S1: Images of the two types of habitat studied, Table S1: Location and fire history of study sites, Table S2: Parameters of generalized mixed models showing the effect of heat, size and habitat type on seed germination of Cistus salviifolius, Table S3: Parameters of generalized mixed models showing the effect of size and habitat type on dormancy strength and seed survival to heat shock of Cistus salviifolius. File S1: Raw data.

Author Contributions: Conceptualization, S.G.-G., M.P. and F.O.; data curation, M.D., S.P. and I.M.-R.; formal analysis, S.G.-G. and M.P.; funding acquisition, F.O.; investigation, S.G.-G., M.D., S.P. and I.M.-R.; project administration, F.O.; resources, F.O.; software, S.G.-G., M.P. and I.M.-R.; supervision, S.G.-G. and F.O.; validation, S.G.-G., M.P. and F.O.; visualization, S.G.-G.; writing—original draft, S.G.-G.; writing-review and editing, S.G.-G., M.P., M.D., S.P., I.M.-R. and F.O. All authors have read and agreed to the published version of the manuscript.

Funding: This study was funded by HERRIZA project, grant number CGL2015-64007-P (MINECO-FEDER, Government of Spain). S.G-G. was partially supported by Comisión Nacional de Investigación Científica y Tecnológica, grant number FONDAP/CONICYT 15110009 (Government of Chile).

Acknowledgments: We thank Ana G. Cervigón and Irati Falces for their help in seed collection and lab work.

Conflicts of Interest: The authors declare no conflict of interest. 


\section{References}

1. Cowling, R.M.; Rundel, P.W.; Lamont, B.B.; Arroyo, M.K.; Arianoutsou, M. Plant diversity in Mediterranean-climate regions. Trends Ecol. Evol. 1996, 11, 362-366. [CrossRef]

2. Keeley, J.E.; Bond, W.J.; Bradstock, R.A.; Pausas, J.G.; Rundel, P.W. Fire in Mediterranean Ecosystems: Ecology, Evolution and Management, 1st ed.; Cambridge University Press: New York, NY, USA, 2012; 515p.

3. Keeley, J.E.; Pausas, J.G.; Rundel, P.W.; Bond, W.L.; Bradstock, R.A. Fire as an evolutionary pressure shaping plant traits. Trends Plant Sci. 2011, 16, 406-411. [CrossRef] [PubMed]

4. Mooney, H.A.; Dunn, E.L. Convergent evolution of Mediterranean-climate evergreen sclerophyll shrubs. Evolution 1970, 24, 292-303. [CrossRef] [PubMed]

5. Paula, S.; Naulin, P.I.; Arce, C.; Galaz, C.; Pausas, J.G. Lignotubers in Mediterranean Basin plants. Plant Ecol. 2016, 217, 661-676. [CrossRef]

6. Pausas, J.G. Bark thickness and fire regime. Funct. Ecol. 2015, 29, 315-327. [CrossRef]

7. Lamont, B.B.; Le Maitre, D.C.; Cowling, R.M.; Enright, N.J. Canopy seed storage in woody plants. Bot. Rev. 1991, 57, 277-317. [CrossRef]

8. Keeley, J.E.; Fotheringham, C.J. Role of fire in regeneration from seed. In Seeds: The Ecology of Regeneration in Plant Communities, 1st ed.; Fenner, M., Ed.; CAB International: Oxford, UK, 2000; pp. 311-330.

9. Pausas, J.G.; Keeley, J.E. Evolutionary ecology of resprouting and seeding in fire-prone ecosystems. N. Phytol. 2014, 204, 55-65. [CrossRef]

10. Flematti, G.R.; Dixon, K.W.; Smith, S.M. What are karrikins and how were they 'discovered' by plants? BMC Biol. 2015, 13, 108. [CrossRef]

11. Moreira, B.; Pausas, J.G. Tanned or burned: The role of fire in shaping physical seed dormancy. PLoS ONE 2012, 7, e51523. [CrossRef]

12. Bell, D.T.; Williams, D.S. Tolerance of thermal shock in seeds. Aust. J. Bot. 1998, 46, 221-233. [CrossRef]

13. Gómez-González, S.; Torres-Díaz, C.; Bustos-Schindler, C.; Gianoli, E. Anthropogenic fire drives the evolution of seed traits. Proc. Natl. Acad. Sci. USA 2011, 108, 18743-18747. [CrossRef] [PubMed]

14. Tangney, R.; Merritt, D.J.; Fontaine, J.B.; Miller, B.P. Seed moisture content as a primary trait regulating the lethal temperature thresholds of seeds. J. Ecol. 2019, 107, 1093-1105. [CrossRef]

15. Hanley, M.; Unna, J.; Darvill, B. Seed size and germination response: A relationship for fire-following plant species exposed to thermal shock. Oecologia 2003, 134, 18-22. [PubMed]

16. Tavşanoğlu, C.; Çatav, Ş.S. Seed size explains within-population variability in post-fire germination of Cistus salviifolius. Ann. Bot. Fenn. 2012, 49, 331-340. [CrossRef]

17. Liyanage, G.S.; Ooi, M.K. Seed size-mediated dormancy thresholds: A case for the selective pressure of fire on physically dormant species. Biol. J. Linn. Soc. 2018, 123, 135-143. [CrossRef]

18. Delgado, J.A.; Serrano, J.M.; López, F.; Acosta, F.J. Heat shock, mass-dependent germination, and seed yield as related components of fitness in Cistus ladanifer. Environ. Exp. Bot. 2001, 46, 11-20. [CrossRef]

19. Ruprecht, E.; Fenesi, A.; Fodor, E.I.; Kuhn, T.; Tökölyi, J. Shape determines fire tolerance of seeds in temperate grasslands that are not prone to fire. Perspect. Plant Ecol. Evol. Syst. 2015, 17, 397-404. [CrossRef]

20. Gómez-González, S.; Ojeda, F.; Torres-Morales, P.; Palma, J.E. Seed pubescence and shape modulate adaptative responses to fire cues. PLoS ONE 2016, 11, e0159655. [CrossRef]

21. Cochrane, A.; Yates, C.J.; Hoyle, G.L.; Nicotra, A.B. Will among-population variation in seed traits improve the chance of species persistence under climate change? Glob. Ecol. Biogeogr. 2015, 24, 12-24. [CrossRef]

22. Moreira, B.; Tavsanoglu, Ç.; Pausas, J.G. Local versus regional intraspecific variability in regeneration traits. Oecologia 2012, 168, 671-677. [CrossRef]

23. Leonard, J.; West, A.G.; Ojeda, F. Differences in germination response to smoke and temperature cues in 'pyrophyte' and 'pyrofuge' forms of Erica coccinea (Ericaceae). Int. J. Wild. Fire 2018, 27, 562-568. [CrossRef]

24. Ojeda, F.; Pausas, J.G.; Verdú, M. Soil shapes community structure through fire. Oecologia 2010, 163, 729-735. [CrossRef] [PubMed]

25. Cowling, R.M.; Kirkwood, D.; Midgley, J.J.; Pierce, S.M. Invasion and persistence of bird-dispersed, subtropical thicket and forest species in fire-prone coastal fynbos. J. Veg. Sci. 1997, 8, 475-488. [CrossRef]

26. Kraaij, T.; van Wilgen, B.W. Drivers, ecology, and management of fire in fynbos. In Fynbos: Ecology, Evolution, and Conservation of a Megadiverse Region, 1st ed.; Allsopp, N., Colville, J.F., Verboom, G.A., Eds.; Oxford University Press: Oxford, UK, 2014; pp. 47-72. 
27. Naveh, Z. The evolutionary significance of fire in the Mediterranean region. Vegetatio 1975, 29, $199-208$. [CrossRef]

28. Trabaud, L. Postfire plant community dynamics in the Mediterranean Basin. In The Role of Fire in Mediterranean-type Ecosystems, 1st ed.; Moreno, J.M., Oechel, W.C., Eds.; Springer: New York, NY, USA, 1994; pp. 1-15.

29. Pausas, J.G.; Verdú, M. Plant persistence traits in fire-prone ecosystems of the Mediterranean basin: A phylogenetic approach. Oikos 2005, 109, 196-202. [CrossRef]

30. Verdú, M.; Pausas, J.G. Fire drives phylogenetic clustering in Mediterranean Basin woody plant communities. J. Ecol. 2007, 95, 1316-1323. [CrossRef]

31. Pausas, J.G.; Keeley, J.E.; Verdú, M. Inferring differential evolutionary processes of plant persistence traits in Northern Hemisphere Mediterranean fire-prone ecosystems. J. Ecol. 2006, 94, 31-39. [CrossRef]

32. Gil-López, M.J.; Segarra-Moragues, J.G.; Ojeda, F. Floristic distinctiveness and endemic richness of woody plants highlight the biodiversity value of the herriza among all Mediterranean heathlands. Plant Ecol. Div. 2018, 11, 111-119. [CrossRef]

33. Gil-López, M.; Segarra-Moragues, J.G.; Ojeda, F. Influence of habitat patchiness on diversity patterns of a habitat specialist plant community. J. Veg. Sci. 2017, 28, 436-444. [CrossRef]

34. Santos, L.; Capelo, J.; Tavares, M. Germination patterns of soil seed banks in relation to fire in Portuguese littoral pine forest vegetation. Fire Ecol. 2010, 6, 1-15. [CrossRef]

35. Thanos, C.A.; Georghiou, K. Ecophysiology of fire-stimulated seed germination in Cistus incanus ssp. creticus (L.) Hey wood and C. salvifolius L. Plant Cell Environ. 1988, 11, 841-849. [CrossRef]

36. Céspedes, B.; Torres, I.; Luna, B.; Pérez, B.; Moreno, J.M. Soil seed bank, fire season, and temporal patterns of germination in a seeder-dominated Mediterranean shrubland. Plant Ecol. 2012, 213, 383-393. [CrossRef]

37. Moretti, M.; Conedera, M.; Moresi, R.; Guisan, A. Modelling the influence of change in fire regime on the local distribution of a Mediterranean pyrophytic plant species (Cistus salviifolius) at its northern range limit. J. Biogeogr. 2006, 33, 1492-1502. [CrossRef]

38. Demoly, J.P.; Montserrat, P. Cistus L. In Flora Ibérica, 1st ed.; Castroviejo, S., Aedo, C., Laínz, M., Muñoz Garmendia, F., Nieto Feliner, G., Paiva, J., Benedí, C., Eds.; Real Jardín Botánico, CSIC: Madrid, Spain, 1993; Volume 3, pp. 319-337.

39. Valdés, B.; Talavera, S.; Fernández-Galiano, E. Flora Vascular de Andalucía Occidental II, 1st ed.; Ketres: Barcelona, Spain, 1987; p. 340.

40. REDIAM. Red de Información Ambiental de Andalucía. Junta de Andalucía. Available online: http: //www.juntadeandalucia.es (accessed on 14 June 2019).

41. De Castro, R.; Simarro, M.E.; Priego, C.; Lafuente, R.; Sancho, A. Investigación social sobre los incendios forestales en Andalucía. In Proceedings of the Wildfire 2007 IV Conferencia Internacional sobre Incendios Forestales, Seville, Spain, 13-17 May 2007.

42. Vuong, Q.H. Likelihood ratio tests for model selection and non-nested hypotheses. Econometrica 1989, 57, 307-333. [CrossRef]

43. Nakagawa, S.; Schielzeth, H. A general and simple method for obtaining R2 from generalized linear mixed-effects models. Methods Ecol. Evol. 2013, 4, 133-142. [CrossRef]

44. R Core Team. R: A Language and Environment for Statistical Computing. R Foundation for Statistical Computing. Available online: http://www.R-project.org (accessed on 22 January 2020).

45. Bates, D.; Sarkar, D.; Bates, M.D.; Matrix, L. The lme4 package. R Package Version 2007, 2, 74.

46. Tavşanoğlu, Ç.; Gürkan, B. Post-fire dynamics of Cistus spp. in a Pinus brutia forest. Turkish J. Bot. 2005, 29, 337-343.

47. Ojeda, F.; Marañón, T.; Arroyo, J. Postfire regeneration of a Mediterranean heathland in southern Spain. Int. J. Wild. Fire 1996, 6, 191-198. [CrossRef]

48. Ojeda, F. Mediterranean heathland and fynbos: A neglected example of convergence between mediterranean climate regions (contributed case study). In The Biology of Mediterranean-Type Ecosystems, 1st ed.; Esler, K.J., Jacobsen, A.L., Pratt, R.B., Eds.; Oxford University Press: Oxford, UK, 2018; pp. 160-163.

49. Paniw, M.; Quintana-Ascencio, P.F.; Ojeda, F.; Salguero-Gómez, R. Interacting livestock and fire may both threaten and increase viability of a fire-adapted Mediterranean carnivorous plant. J. Appl. Ecol. 2017, 54, 1884-1894. [CrossRef] 
50. Delgado, J.A.; Serrano, J.M.; López, F.; Acosta, F.J. Seed size and seed germination in the Mediterranean fire-prone shrub Cistus ladanifer. Plant Ecol. 2008, 197, 269-276. [CrossRef]

51. Escudero, A.; Núñez, Y.; Pérez-García, F. Is fire a selective force of seed size in pine species? Acta Oecol. 2000, 21, 245-256. [CrossRef]

52. Thanos, C.A.; Georghiou, K.; Kadis, C.; Pantazi, C. Cistaceae: A plant family with hard seeds. Isr. J. Plant Sci. 1992, 41, 251-263.

53. Pérez-García, F.; Escudero, A. Role of the seed coat in germination of Cistus populifolius L. Isr. J. Plant Sci. 1997, 45, 329-331. [CrossRef]

54. Luna, B.; Chamorro, D.; Pérez, B. Effect of heat on seed germination and viability in species of Cistaceae. Plant Ecol. Div. 2019, 12, 151-158. [CrossRef]

55. Grundy, A.C.; Mead, A.; Burston, S. Modelling the emergence response of weed seeds to burial depth: Interactions with seed density, weight and shape. J. Appl. Ecol. 2003, 40, 757-770. [CrossRef]

56. Saatkamp, A.; Cochrane, A.; Commander, L.; Guja, L.K.; Jimenez-Alfaro, B.; Larson, J.; Nicotra, A.; Poschlod, P.; Silveira, F.A.O.; Cross, A.T.; et al. A research agenda for seed-trait functional ecology. N. Phytol. 2019, 221, 1764-1775. [CrossRef]

57. Jiménez-Alfaro, B.; Silveira, F.A.; Fidelis, A.; Poschlod, P.; Commander, L.E. Seed germination traits can contribute better to plant community ecology. J. Veg. Sci. 2016, 27, 637-645. [CrossRef]

(C) 2020 by the authors. Licensee MDPI, Basel, Switzerland. This article is an open access article distributed under the terms and conditions of the Creative Commons Attribution (CC BY) license (http://creativecommons.org/licenses/by/4.0/). 